\title{
PROJETO PARA UMA REVOLUÇÃO URBANA EM GOIÂNIA OU: O SER É COM PERUCAS
}

Horácio Costa

\author{
Vc, perspicaz leitor, já \\ descobriu que estou parodiando \\ Robbe-Grillet, certo? \\ Mas não só de sombras textuais \\ coagula-se o texto, como alguém \\ que na traquéia tivesse, pobre, \\ um bolo de farofa. \\ Não: também por evidência poética \\ que o terceiro olho ou o do sol negro \\ (outro francês: Artaud, Héliogabale) \\ percebe na primeira piscadela: \\ vós, bichas goianas, \\ estais abandonadas pelo espaço \\ embora vos encontreis \\ em posição estratégica: \\ frente a Brasília! posto \\ que habitais a última urbe \\ capital com esquinas e coreto \\ antes da Federal onde, \\ como sabemos tod@s, \\ não há boas intenções \\ que não apodreçam. \\ Necessitais não só de espaço para vós \\ marcado como vosso como as iniciais \\ no lombo da manada \\ nessa Goiânia marcada por cow-boys, \\ mas também de algo excelso! \\ Urge-vos, portanto, encontrardes \\ protetora ou patronesse. \\ Necessitais de apoio estrutural: \\ nada a ver com quem assina pletoras \\ de abaixo-assinados no site do AVAAZ \\ e logo, incontinenti, dedica-se sem pejo \\ a um canal de pegação. \\ Afinal, este é um país com muitos \\ vales, buracos, poços, depressões \\ e tão poucas montanhas. Os cumes, \\ por exemplo, são todos excelsos! \\ e mesmo se apenas metafóricos: \\ que se convertam em muralha \\ contra as hostes de Brasília \\ e proteção nossa, que vivemos mais
}


ao Sul. Sede heróicas e crieis recantos à vossa medida nessa urbe que exsuda ortogonalidade modernolátrica. Recordo-vos que nesta terra na qual em se plantando etc. já se erigiram haut-lieux viados - em SP o Arouche no Rio o Aterro bem como illo tempore escolhemos patronas, patronesses. a Virgem Negra vide de Aparecida e ninguém superou Carmem Miranda, ungida como embaixadora e garantia da brasileira cláusula pétrea de Felicidade Compulsória, mesmo se estiver essa alicerçada em Nembutal.

Proponho-vos assim este projeto de democratização urbana: para terdes o vosso equivalente ao room of one's own woolfiano no público espaço onde o urbanismo vos esqueceu e às vossas sinuosas proclividades, e tudo isto posto sugiro não uma patrona, já que a posição tomada está, mas sim uma patronesse porque há uma muito boa dando sopa e que tem que ver convosco. Isabel Maria de Alcântara Brasileira foi nomeada Duquesa de Goiás por seu pai o nosso Defensor Perpétuo - como no plinto está escrito de sua estátua roubada na fronteira entre Pacaraima e a Venezuela como provável estocada a favor de Domitila no coração de Leopoldina: são dados da petite histoire com os quais deveis não importardes, como tampouco com o dela não haver posto nunca seus ducais pés em Goyaz: ¿y qué?, considerando que Agripina jamais botou os seus, patrícios, naquela colônia junto ao Reno que levava o seu nome por desejo de Nero e hoje é Köln? Já tendes, assim, uma Duquesa que vos faça jus até mesmo quando filmardes no futuro um épico viado como Priscilla Queen of the Desert em cenário do centro-oeste brasileiro, 
e vos dispense uma inspiração tão legendária como só um vetor do imaginário acrisola: assim, valha-nos deus, em sua prodigalidade narrativa. Faltará escolher para o tal Bulevar Duquesa de Goiás não só o sítio a ser por vós ocupado mas também plantas que façam recordar as tranças e bandós vitorianos como aquelas da protagonista do imortalíssimo filme $O$ Piano e que ornam as laterais da cabeça da bastarda de Pedro e Domitila na sua única imagem encontrada na Wikipédia: serpentinas lustrosas de cachos negros sobre pele morena, e que terão chamado a atenção de seus receosos vizinhos mecklemburgueses. E não só jibóias e costelas-de-Adão mas também o local onde se erga em privilegiado espaço retórico uma escultura em escala 100:1 tal e como as obras de Claes Oldenburg distribuídas pelos gramados das cidades ditas de alta civilização:

sim, em forma de peruca, em forma de uma brilhantíssima, estonteante, maravilhosa peruca que flutue e se arvore em pendão de esperança entre prédios de vil arquitetura, e que seja excelsa como um cume e não só: como uma espécie de altar profano: um verdadeiro ara sacratissimo já que sabemos tod@s que, porra, o ser é com perucas, que não ontologias.

Assim seja. Amém. Ide em paz. Goianas, empoderai-vos, amai-vos, defendei-nos. O fato Brasília vo-lo reclama e o Br@sil conta convosco.

Osasco, 19-21 V 2018 